\title{
New contribution to knowledge of Sienese scleractinians
}

\author{
Valeriano Spadini
}

Via A. Toti 4, 52046 Lucignano, Arezzo, Italy; e-mail: spadiniv@inwind.it

\begin{abstract}
In this new contribution to knowledge of scleractinians from the Pliocene of Siena, some species belonging to genera common in the Pliocene (Caryophyllia, Flabellum, Balanophyllia, Cladopsammia and Dendrophyllia) are described. One species is attributed, albeit dubiously, to a genus not hitherto reported from the Pliocene of the Mediterranean (Anomocora). Some aspects of the variability of other previously described species are also highlighted (Madracis almerai, Bathelia sp., Trochocyathus sp., Stephanocyathus elegans, Desmophyllum sp., Cladopsammia sp. Enallopsammia sp.) (Spadini, 2015). The generic nomenclature of a species of the Caryophylliidae remains open.
\end{abstract}

KEY WORDS Pliocene; Sienese; scleractinians; new reports.

Received 11.02.2021; accepted 04.06.2021; published online 30.06.2021

\section{INTRODUCTION}

The scleractinian fauna of the Pliocene of Siena was first described by Spadini (2015) and there have been three subsequent additions (Spadini 2016, 2018, 2020). To date, a total of 60 species belonging to 29 genera and 10 families have been reported.

This new contribution describes some species found in the central and southern part of the province of Siena (Caryophyllia (Caryophyllia) cf. smithii, Anomocora sp., Flabellum cf. alabastrum; Balanophyllia italica; Cladopsammia sp. 1; Dendrophyllia cf. ramea). Most of the new reports are from deposits of Monte Calcinaio, a rich scleractinian site in the sub-basin of Radicofani. Other species were found in deposits from the Zanclean of Montalcino, from the Piacentian of I Sodi in the Siena sub-basin and from the late Piacentian or early Gelasian of Cava Tempora in the Val di Chiana basin.

Other well-known species reported from the Siena-Radicofani basin (Spadini, 2015) are mentioned briefly in order to specify some characteris- tics (Madracis almerai, Bathelia sp., Stephanocyathus elegans, Trochocyathus sp., Cladopsammia sp., Enallopsammia sp. etc.). The generic nomenclature of one species, assigned to the Caryophylliidae, remains open.

For the general characteristics of the study area and for Material and Methods see Spadini (2015).

\section{RESULTS}

\section{Systematic Palaeontology}

Ordo SCLERACTINIA Bourne, 1900

Subordo ASTROCOENIINA Vaughan et Wells, 1943

Familia POCILLOPORIDAE Gray, 1842

Genus Madracis Milne Edwards et Haime, 1849

Type Species. Madracis asperula Milne Edwards et Haime, 1849, by monotypy. 
Madracis almerai (De Angelis, 1895) - Figs. 1-3

Madracis almerai. Spadini 2015: 28-29, figs. 6-9

Material examined. Monte Calcinaio: three specimens.

Remarks. The fossil species of the Pliocene of the Mediterranean are believed to be similar to the species currently living in the Mediterranean Sea (Spadini, 2015). Madracis almerai shows great intraspecific variation in colony morphology. Some fragments are very small, while others are cylindrical, 5 to $10 \mathrm{~mm}$ in diameter and 10 to $20 \mathrm{~mm}$ in height. We can suppose that Madracis almerai is digitiform or branching.

Madracis almerai is very common in graveland pebble-rich facies representing the infralittoral strata of the Monte Calcinaio.

Familia CARYOPHYLLIIDAE Dana, 1846 Subfamilia CARYOPHYLLIINAE Dana, 1846

Genus Caryophyllia Lamarck, 1801

TYPE SPECIES. Madrepora cyathus Ellis et Solander, 1786, by subsequent designation (Broderip, 1828).

Caryophyllia (Caryophyllia) cf. smithii Stokes et Broderip, 1828 - Fig. 4

Caryophyllia clavus Scacchi, 1935: 17.

Cyathina turbinata Philippi, 1836: 54, pl. 4, fig. 18; pl. 12, fig. 24.

Cyathina pseudoturbinolia - Milne Edwards \& Haime, 1848: 19, pl. 9 fig. 1.

Caryophyllia felsinea var. gigantea Montanaro, 1931: 71, pl. 4, fig. 10a, b.

Caryophyllia smithii - Vertino 2003: 157-163, pl. VIII-IX.

Material examined. Cava Tempora: three specimens.

DESCRIPTION. Corallum regularly conical, 17.2 $\mathrm{mm}$ tall with narrow $3.3 \mathrm{~mm}$ diameter of base. Theca with costae equal or nearly equal, granular and of variable width.

At the base there are 48 costae, each consisting of a single row of granules. In the medial zone of the theca the costae consist of several granules paired or expanded horizontally and, near the calice, the costae corresponding to the primary and secondary septa are more developed and raised.

Calice regularly elliptical. Calicular diameter $13.4 \times 11.3 \mathrm{~mm}(\mathrm{~d} / \mathrm{D}$ ratio $=0.84)$. Septa of the first two cycles equal or nearly equal, exsert; septa of third cycle less exsert. Septa of fourth cycle about half as long as those of third cycle.

The smaller specimens $(\mathrm{D}=8-10 \mathrm{~mm})$ have 48 septa, one specimen with $\mathrm{D}=13 \mathrm{~mm}$ has 58 septa in 14 systems. The edge of the septa is continuous and straight. Pali of similar length to the corresponding septa $\left(\mathrm{P}_{3}=\mathrm{S}_{3}\right)$, separated by deep narrow notch. The granulation of the pali is more pronounced than that of the septa and often consists of concave lamellae. Columella elongated, but not entirely preserved in any of the specimens examined.

StRATIGRAPHiC Distribution. Caryophyllia clavus is cited from the Miocene of Forchtenau (Reuss 1871), the Tortonian of Montegibbio (Namias, 1892), the Molassa of Baviera (Kühn, 1965), the Pliocene of Spain (De Angelis, 1895), Piemonte and Liguria (Osasco, 1895), Emilia (Simonelli, 1895), Rhodes (Jussen, 1892), Puglia (Scacchi, 1935) and Montanaro (1931) and the Pleistocene of Sicilia and Calabria (Seguenza, 1880; De Stefani, 1955; Sganga, 1978; Vertino, 2003).

Remarks. The name Caryophyllia clavus was given to a fossil from the Plio-Pleistocene of Gravina (Apulia, Italy), the type or topotypical material of which has never been studied in detail. According to Scacchi, C. clavus resembled an extant Caryophyllia of the Gulf of Naples, that matched Cyathina turbinata Philippi, 1836. Despite their resemblance, the correspondence is uncertain. Cyathina turbinata is a junior synonym of Caryophyllia smithii Stokes et Broderip, 1828 , from the Mediterranean Sea and the northeastern Atlantic Ocean (Zibrowius, 1980; Vertino, 2003).

Michelin (1841) assigned the name Caryophyllia pseudoturbinolia to a fossil from Sicily and to another living in the Mediterranean. It is unclear whether the description and the figure refer to the fossil or the living form, but they seem identical to Cyathina turbinata. 


\section{Bathelia sp.}

Bathelia sp. - Spadini, 2016: 219-222.

REMARKS. In the first contribution on the Scleractinian fauna of the Siena area (Spadini, 2015), one species was proposed as an "undetermined Oculinidae". It was later reported as Bathelia sp. (Spadini, 2016) and was subsequently also reported from the Pliocene of Spain (Spadini, 2019).

From a macromorphological point of view, this species can be attributed to Bathelia (type species Bathelia candida Moseley, 1881 by monotypy), a monotypic genus with a geographical distribution limited to the coasts of South America, by virtue of its colonial form and its crown of pali opposite $\mathrm{S}_{3}$, according to Wells (1956) and Chevalier (1987), and also according to the determination key proposed by Cairns \& Kitahara (2012). However, the calycinal characters of Bathelia candida are different from those of the fossil Bathelia. These characters bring the Sienese fossil closer to the Caryophylliidae family than to the Oculinidae. Moreover, the systematic position of the fossil findings of Radicofani sub-basin is questioned in a review of the deep sea Quaternary corals of Argentina (Garberoglio et al., 2020).

H. Zibrowius (pers. comm. 4/06/2020) recently suggested that this species could be correlated with the genus Sclerhelia (type species Madrepora hirtella Pallas, 1766 by monotypy). Sclerhelia hirtella (Pallas, 1766) was redescribed by Zibrowius (2007) on samples from Saint Helena (southern Atlantic) and was assigned to the family Caryophylliidae.

Vaughan \& Wells (1943) and Wells (1956) only refer to recent Sclerhelia colonies from the southern Atlantic and the Indo-Pacific. More recently Chevalier (1962) described Sclerhelia tauriniensis, a fossil species from the Miocene of Turin (northern Italy). However, since the latter was described from a small fragment in rather poor condition, it probably does not belong to the genus Sclerhelia.

It is hard to make a precise comparison of living specimens of Sclerhelia and fossil specimens from the Mediterranean Sea first assigned to Bathelia, since the fossil specimens consist of fragments, probably of terminal branches.

The Mediterranean fossil Bathelia are characterized by calices with 48 septa and 12 pali opposite
$\mathrm{S}_{3}$, with elliptical calices $>10 \mathrm{~mm}$ in diameter. The fragments appear to show sympodial growth. In some cases the branches have dichotomous growth with a calice between them. The theca is finely granular or costate near the calice. The specimens from the Pliocene of Spain are very similar, and may have a circular calice, but always 48 septa and 12 pali.

The extant species Sclerhelia hirtella has "calices subcircular to slightly elliptical, shallow, densely filled up with septa, pali, and columella elements, up to 6-7 $\mathrm{mm}$ in diameter on thicker branches, smaller on younger, more slender terminal branches" (Zibrowius, 2007). The columella is massive with one palar crown opposite $\mathrm{P}_{2}$, often very incomplete. The surface is finely granular or costate in Sclerhelia and is very similar to that of "Bathelia" fossils.

At the moment it can be safely stated that the Mediterranean Pliocene fossil seems more similar to Sclerhelia than to Bathelia.

\section{Genus Stephanocyathus Seguenza, 1864}

TyPe SPECIES. Stephanocyathus elegans Seguenza, 1864 for subsequent designation (Wells, 1936).

Stephanocyathus elegans Seguenza, 1864 - Fig. 5

Type Material. The Seguenza collection was destroyed during the earthquake of Messina in 1908. A specimen from the "Miocene" of Scoppo (IGF3075E) is preserved in the Institute of Geology and Palaeontology, Florence (Spadini, 2015).

Material examined. Pian delle Cortine: one specimen.

DESCRIPTION. Corallum circular in shape (diameter of $15 \mathrm{~mm}$ ), not complete at the edge, with convex base, pedunculate in the centre. Costae corresponding to $\mathrm{C}_{1}$ and $\mathrm{C}_{2}$ evident and raised. The others, more or less regular, formed by a succession of granules. Septa in four complete cycles. $\mathrm{S}_{1}$ and $\mathrm{S}_{2}$ dominant, $\mathrm{S}_{3}$ connected to $\mathrm{S}_{2}, \mathrm{~S}_{4}$ rudimentary and not very evident. Possible presence of $\mathrm{S}_{5}$, but they are not preserved. Columella composed of numerous papillae fused together.

StRatigraphic Distribution. Seguenza (1864, 1880 ) reports $S$. elegans and $S$. elegans var. sub- 
spinosus from the Plio-Pleistocene of Sicily and Calabria (Seguenza, 1864). Simonelli (1895) reports it from the Pliocene of Ponticello di Savena, near Bologna, and describes a new variety: Stephanocyathus elegans var. hemisphaerica Simonelli, 1895. Placella (1978) reports three species from the Pleistocene clays of Archi (Reggio Calabria): $S$ elegans, $S$. zancleus and $S$. variabilis Seguenza, 1864.

REMARKS. The specimen recovered, incomplete, seems to match the specimen of $S$. elegans Seguenza, 1864 from the "Miocene" of Scoppo, figured by Spadini (2015). Spadini (2015) highlights similarity of the IGF specimen with $S$. variabilis Seguenza, 1864, considered by Vertino (2003) to be a subspecies of $S$. elegans.

Genus Trochocyathus Milne Edwards et Haime, 1848

TYPE SPECIES. Turbinolia mitrata Goldfuss, 1826 by subsequent designation (Milne Edwards \& Haime, 1850). Chevalier (1961) following Alloiteau (1952) indicates T. plicatus Michelotti, 1838. as type species.

\section{Trochocyathus sp. - Fig. 6}

Material examined. Monte Calcinaio: one specimen.

DESCRIPTION. Corallum turbinate, free, not completely preserved. Calice slightly oval (diameter $12.2 \mathrm{~mm}$ ). Outer surface slightly granular with twelve costae coinciding with $\mathrm{S}_{1}$ and $\mathrm{S}_{2}$, more granular in the upper half of the corallite and cristate near the calice. The costae are separated by a fine groove consisting of a series of microscopic holes.

Septa 48 in number, arranged in four complete cycles. $\mathrm{S}_{1}$ and $\mathrm{S}_{2}$ exsert, $\mathrm{S}_{3}$ slightly exsert, $\mathrm{S}_{4}$ more exsert than $S_{3} . S_{2}$ thinner than $S_{1}, S_{3}$ fused with $\mathrm{S}_{2}$ deep in the calice. $\mathrm{S}_{4}$ free and half the length of $\mathrm{S}_{1}$. Pali opposite the first three cycles of septa, but main $S_{1}$ are separate from the columella and lack the corresponding pali. The pali of the first two cycles, thick and robust, form a crown closer to the columella, while those of the third cycle are thinner and form a crown larger than those of the first two cycles. Septa and pali with granules, disposed apparently without order. Granuli of the first cycle of pali more robust than others.
Columella fascicular, composed of few twisted lamellar elements, arranged along the major axis of the calice.

REMARKS. This specimen shows some affinity with the specimens described as Trochocyathus affinis Reuss, 1871 from Siena (Spadini, 2015, fig. 107).

Genus Anomocora Studer, 1878

Type Species. Coelosmilia fecunda Pourtalès, 1871 , by monotypy.

DiAGNOSIS. Corallum colonial and recumbent. New corallites, budding extracalicularly from edge zone and detaching from parent corallum, result in corallites with an open or broken base. Paliform lobes sometimes present. Columella trabecular. Endothecal dissepiments present.

REMARKS. Anomocora is a genus of recumbent scleractinian belonging to the subfamily Parasmilinae of the family Caryophylliidae. There are two extant species: Anomocora fecunda (Portualès, 1871) widespread in the Atlantic Ocean and A. carinata Cairns 1991 of the eastern Pacific (Cairns, Hoeksema \& Van der Land, 1999; Cairns, 1979; Zibrowius, 1980).

Anomocora is very similar to Coenosmilia, but is distinguished by regeneration from the edge-zone with detached second-generation buds, whereas Coenosmila forms bushy colonies. Both are characterized by reduced columella, although Anomocora may show paliform lobes (Cairns, 1979, 2000; Zibrowius, 1980).

Zibrowius (1980) considers Anomocora a more recent synonym of Coenosmilia, whereas Cairns (1979) and Cairns \& Kitahara (2012) consider them to be distinct genera.

A fossil species of the genus Anomocora is $A$. rarogemmans Chevalier, 1962 from the Middle Miocene of the Collina di Torino (Chevalier, 1962). The species is known from the holotype and two topotypes from Grancia (Collina di Torino), and another corallite from Sciolze (Torino) (Chevalier, 1961), all stored at the MNHN. Zibrowius (1980) considered this attribution of genus to be uncertain.

Anomocora sp. - Figs. 8-13

Material EXAMined. 24 specimens with calice. 


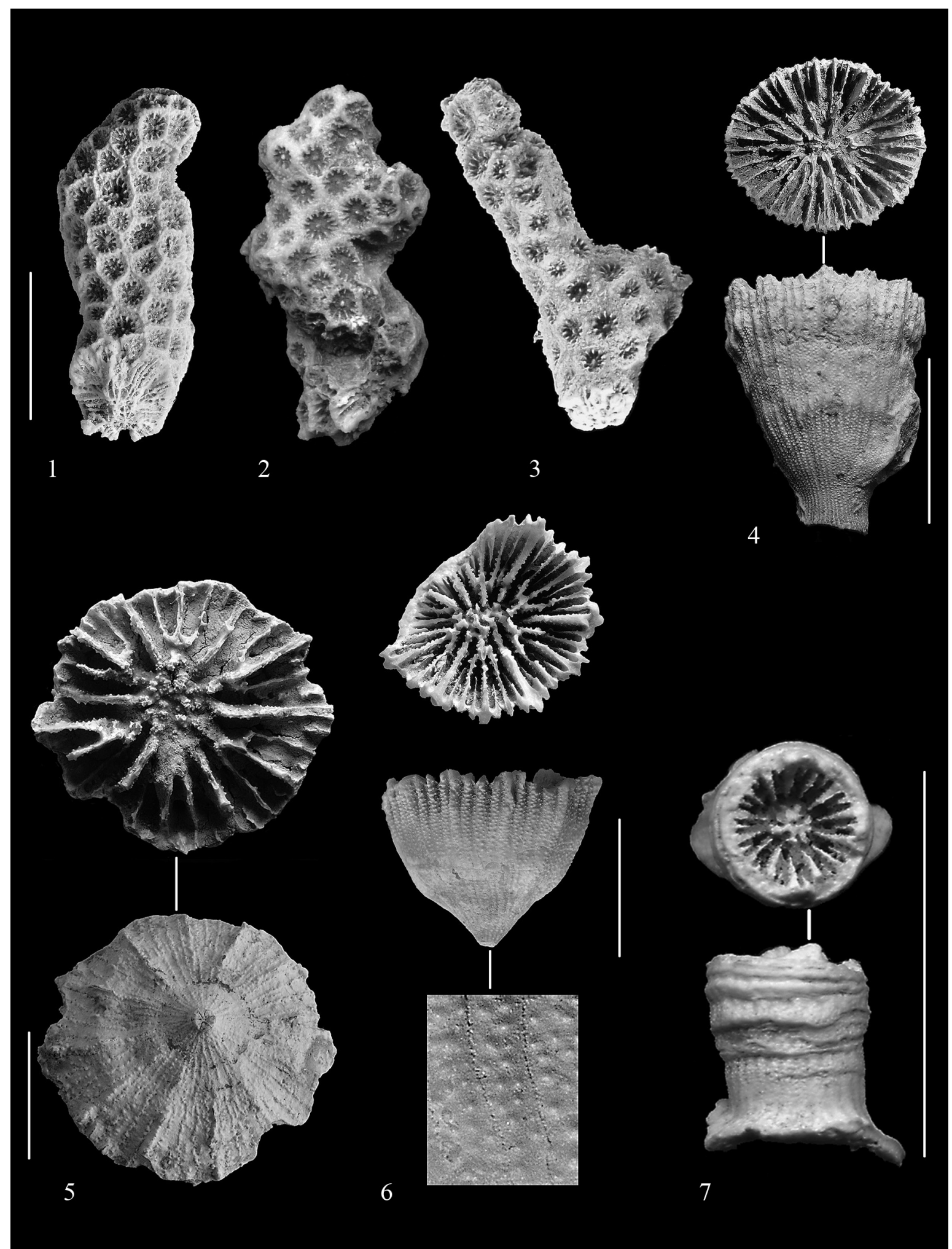

Figures 1-3. Madracis almerai (De Angelis, 1894). Zanclean of Monte Calcinaio. Figure 4. Caryophyllia cf. smithii Stokes et Broderip, 1828 Piacentian of Cava Tempora. Figure 5. Stephanocyathus elegans Seguenza, 1864. Zanclean of Pian delle Cortine. Figure 6. Trochocyathus sp. Zanclean of Monte Calcinaio. Fig. 7. Undetermined Caryophylliidae. Zanclean of Monte Calcinaio. Scale bar $=10 \mathrm{~mm}$. 
DESCRIPTION. Very small colonies, up to $16.6 \mathrm{~mm}$ tall, consisting of a straight corallite, slightly conical, always with an open base, curved distally, also at a right angle. Near the calice there are two or three small incomplete buds, with a maximum diameter of $2 \mathrm{~mm}$. Theca usually with fine granulation, rarely with costae, sometimes more evident distally.

Calice irregularly circular, maximum diameter $2.6 \mathrm{~mm}$, with a fine edge. Fossa very deep. Septa not exsert and not projecting from the edge of the calice, disposed in four incomplete cycles and six systems. Septa very weak and lamellar, short, subequal, numbering 26 to 38. Distal edge of septa smooth. Lateral sides of septa bear many fine even granules, slightly inclined, roughly aligned along growth lines. Paliform lobes absent.

Columella very reduced at bottom of calice. Tabular dissepiments present.

Remarks. This small species of Anomocora from the Pliocene of Monte Calcinaio has dimensions and shape similar to those of Anomocora rarogemmans Chevalier, 1961 from the Miocene of the Collina di Torino.

Undetermined CARYOPHYLLIIDAE - Figs. 7, $14-15$

Material eXAmined. Monte Calcinaio: several specimens.

DesCRIPTION. Cylindrical or tympanoid corallum, solitary, small. The base seems to be polycyclic in some specimens, but in larger ones this character cannot be identified. This may depend on filling of interseptal spaces.

The theca, with granuli or fine costae, is covered by the epitheca, which is especially developed near the calice, forming rings that completely cover the theca, hiding the granulations.

Fossa shallow. Calices circular, septa up to 42 in number, although a large incomplete specimen seems to have 48 septa. The septa and columella are damaged or missing in all specimens.

The two almost complete specimens have 34 septa arranged in four incomplete cycles and six systems. $\mathrm{S}_{1}$ large, $\mathrm{S}_{2}$ slightly thinner, reaching the columella deep in the calice. $S_{3}$ thin, about half as long as $\mathrm{S}_{1}$. $\mathrm{S}_{4}$ very small. Pali arranged before the first two cycles of septa. Those before $S_{1}$ smaller and radially developed, those before $\mathrm{S}_{2}$ and $\mathrm{S}_{3}$ wider, fused together, cylindrical and tuberculate. Columella consisting of few papillae.

REMARKS. This species lived in coarse gravel of the infralittoral zone, and several specimens were found attached to pebbles of various sizes. The specimens resemble Ceratotrochus (s.s.) in certain characters of the calice but other differences distinguish them.

Familia FLABELLIDAE Bourne, 1905

Genus Flabellum Lesson, 1831

TYPE SPECIES. Flabellum pavoninum Lesson, 1831 by monotypy.

Flabellum cf. alabastrum Moseley 1873 - Fig. 16

Material examined. Pian delle Cortine (one fragment).

DESCRIPTION. A fragment of the calycinal margin of a large specimen $(40 \mathrm{~mm})$ showing good correspondence with some representations of $F$. alabastrum (Altuna \& Rios, 2014). Calicular margin strongly and regularly cusped due to equally exsert projection of septa $\mathrm{S}_{1}-\mathrm{S}_{3}$. Wall costate, with $\mathrm{C}_{1}-\mathrm{C}_{3}$ well developed and $\mathrm{C}_{4}-\mathrm{C}_{5}$ inconspicuous.

REMARKS. This fragment was found in association with the previously described specimen of Stephanocyathus. Both species are typical of bathyal environments.

Familia DENDROPHYLLIIDAE Gray, 1847

Genus Balanophyllia Wood, 1844

TYPE SPECIES. Balanophyllia calyculus Wood, 1848 , by monotypy.

Balanophyllia (Balanophyllia) italica Michelin, 1841 - Fig. 18

Caryophyllia italica Michelin, 1841: 46, pl. 9, fig. 15 .

Balanophyllia striatissima Sismonda, 1871: 291; pl. 1, fig. 5 


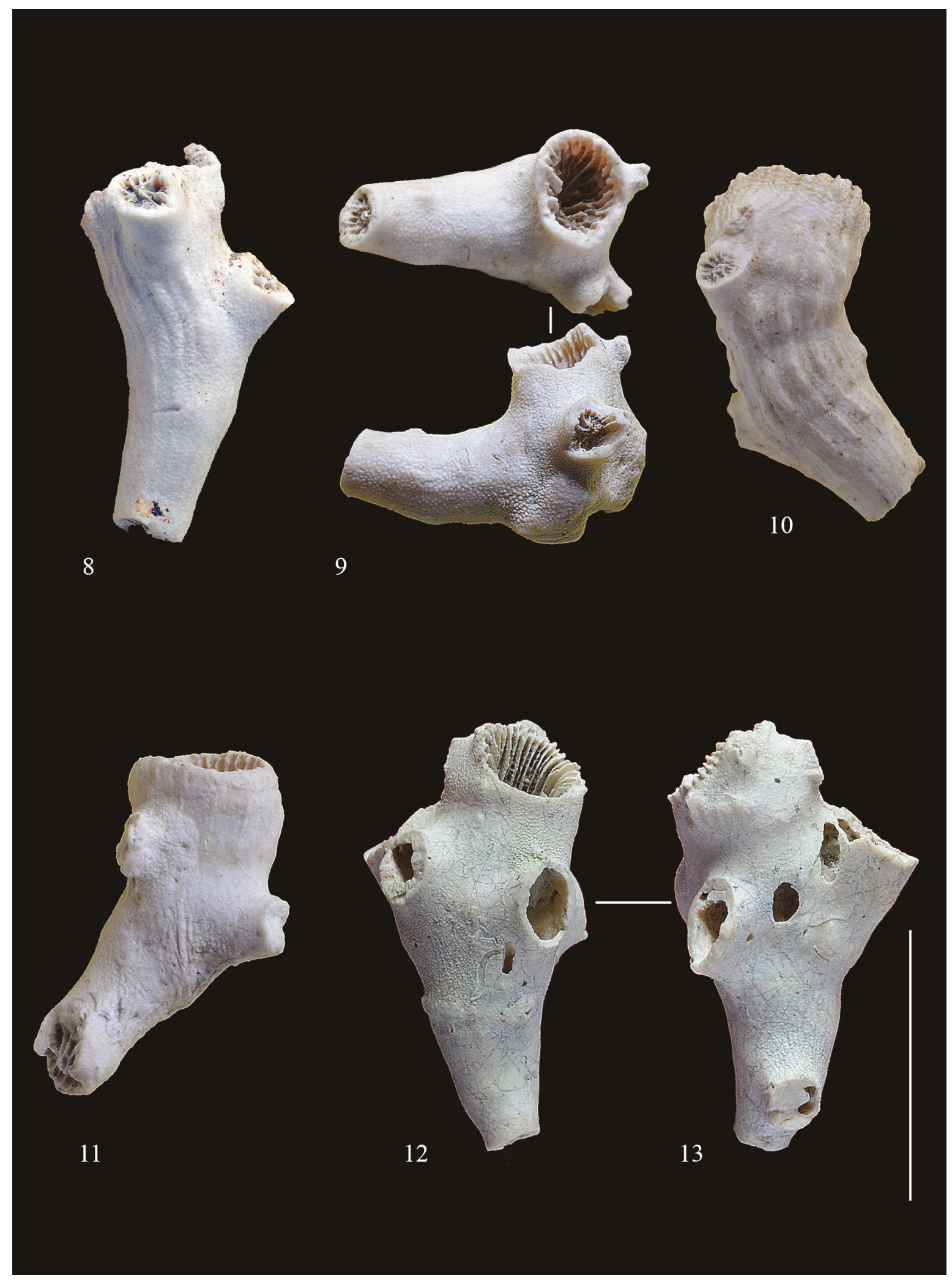

Figures 8-13. Anomocora sp. Zanclean of Monte Calcinaio $($ Scale bar $=10 \mathrm{~mm})$. 
Balanophyllia italica - Milne Edwards \& Haime, 1848: 86.

Balanophyllia italica - Chevalier, 1961: 458-459, texte-fig. 172-174, 176a, 184a.

Balanophyllia (Balanophyllia) italica - Chaix, Cahuzac \& Cluzaud, 1999: 50-51, fig. 4.8-9; Fig. 5.5-6

MATERIAL EXAMINED. Quercecchio: one incomplete specimen.

DESCRIPTION. Corallum solitary, subcylindrical, with large base, $22.8 \mathrm{~mm}$ tall and calice diameter $11.6 \times 14.7 \mathrm{~mm}$.

Costae separated by narrow intercostal furrows and bear strong unequal granules, finely toothed, arranged in a row, except at the base, where they are sometimes covered by a thin layer of epitheca. Calice elliptical, not well preserved.

Septa arranged in five cycles according to the Pourtalès plan. Lateral faces of septa with many fine pointed granules. Pores present in axial and peripheral part of $\mathrm{S}_{4}, \mathrm{~S}_{5}$ and $\mathrm{S}_{6}$. Columella elongated but not preserved. Rare endothecal dissepiments.

REMARKS. A very similar but much larger species of Balanophyllia (up to about $10 \mathrm{~cm}$ in height) is reported as B. gigantea Osasco, 1895 from the sub-basin of Siena by Spadini (2015).

Genus Cladopsammia Lacaze-Duthiers, 1897

TYPE SPECIES. Cladopsammia rolandi LacazeDuthiers, 1897, by monotypy.

Cladopsammia sp. 1 - Figs. 19-21

Cladopsammia sp. - Spadini, 2015: 121-122, fig. 162.

Material examined. Monte Calcinaio: one colony already described in Spadini (2015), other smaller colonies and numerous isolated corallites.

REMARKS. Several colonies of small size and irregular shape have been found. These colonies are generally compact, with corallites always fractured (maximum diameter $8 \mathrm{~mm}$ ), extending in all directions. Septa arranged in four cycles, according to a well-developed Pourtalès plan; pali absent and columella small and papillose. The corallites are covered by a thick epitheca.
Some isolated corallites have lateral buds in various stages or degrees of complexity. It is believed that these colonies originate from single corallites by budding.

?Cladopsammia sp. 2 - Figs. 22-24

Balanophyllia (?) sp. - Spadini, 2015: 119-120, fig. 161.

Material eXAmined. Monte Calcinaio: several specimens.

DESCRIPTION. Isolated, straight or curved coralla, maximum $9.3 \mathrm{~mm}$ tall, covered by a smooth epitheca, with the buds originating from the largest corallites completely covered by a thick epitheca. Regularly rounded calice $5.5 \mathrm{~mm}$ in maximum diameter, septa in four very irregular incomplete cycles according to the Pourtalès plan. Hemispherical columella, spongy, rather prominent.

REMARKS. This species is characterized by small corallite size and by a regularly smooth epitheca that completely covers corallites, costae and pores. It differs from the previous species by virtue of its regular epitheca, many buds usually arranged along the main corallite, its evident hemispherical columella and smaller dimensions.

A corallite of this species, with no lateral buds, is illustrated in Spadini (2015) as Balanophyllia (?) sp.

Genus Dendrophyllia Blainville, 1830

TYPE SPECIES. Madrepora ramea Linnaeus, 1758 , by subsequent designation (Milne Edwards \& Haime, 1850).

Dendrophyllia cf. ramea Linnaeus, 1758 - Fig. 17

Material examined. Monte Calcinaio: one colony.

DESCRIPTION. Corallum cylindrical, $68 \mathrm{~mm}$ tall, with maximum diameter $19.2 \mathrm{~mm}$, consisting of a central branch, slightly compressed, with two series of lateral calices, slightly prominent, partially preserved, the arrangement of which is not very regular. The corallite was probably bifurcate, but the state of conservation of the colony leaves a margin of uncertainty. The costae are straight or flexuous, 


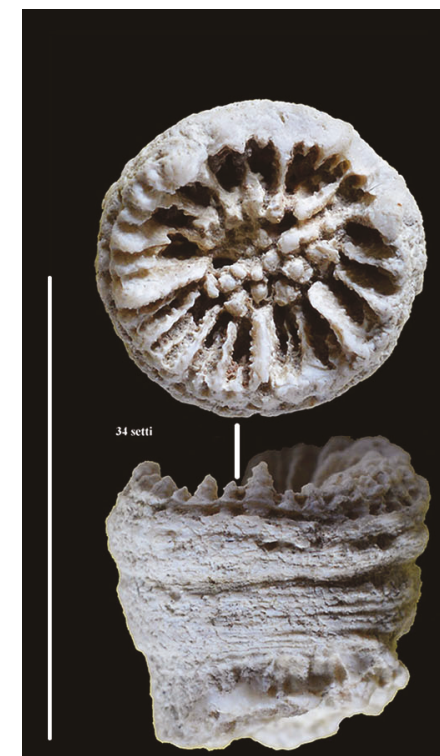

14

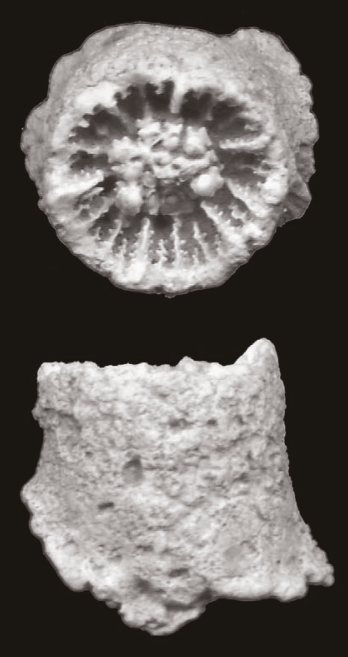

15

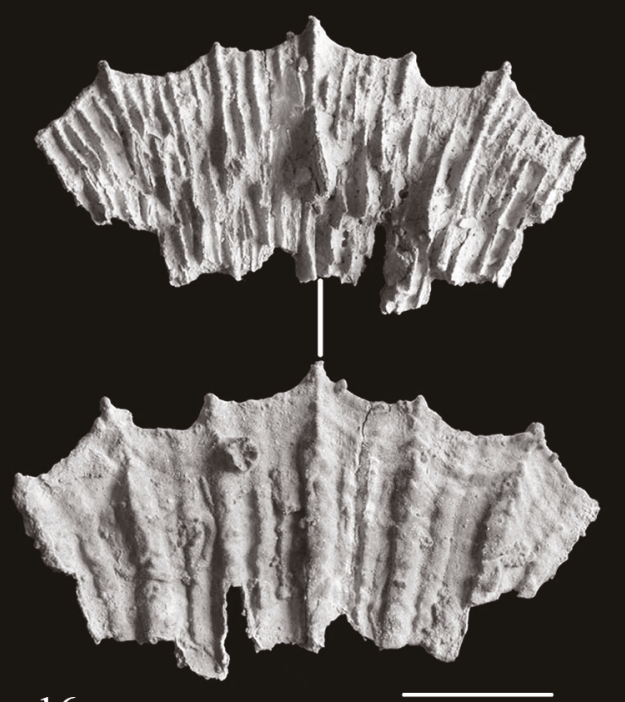

16

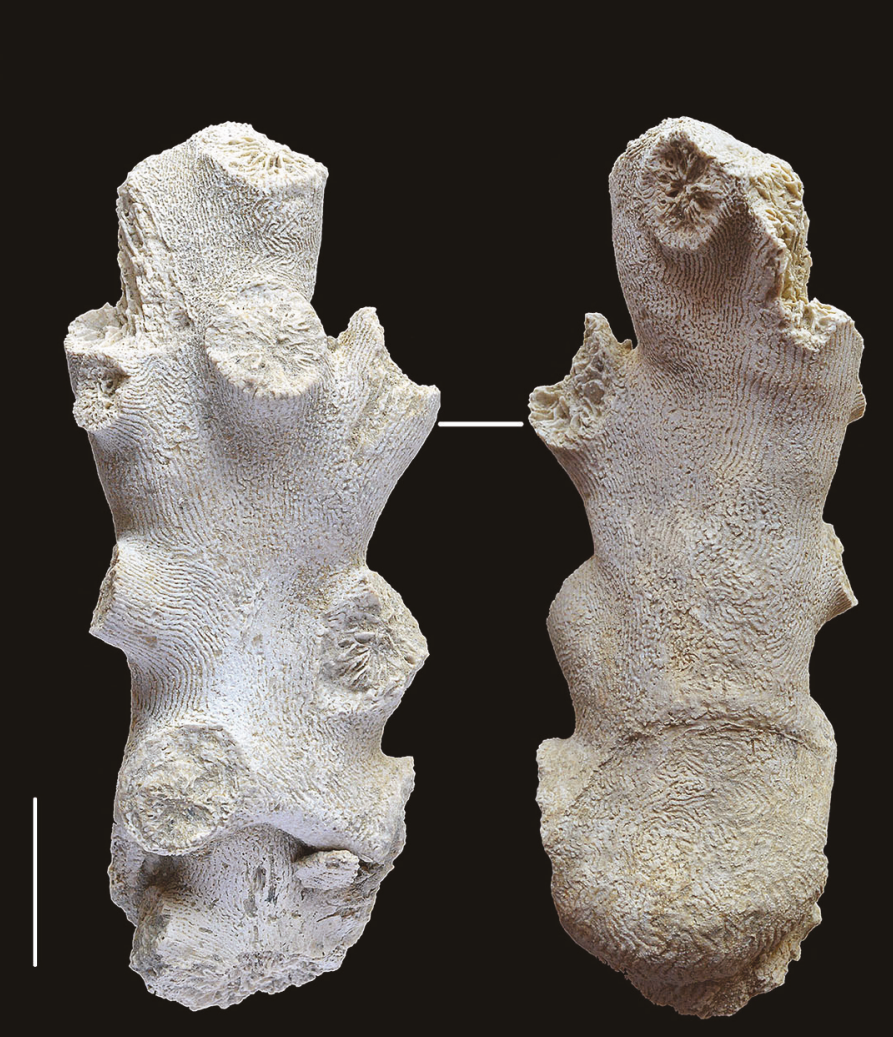

17

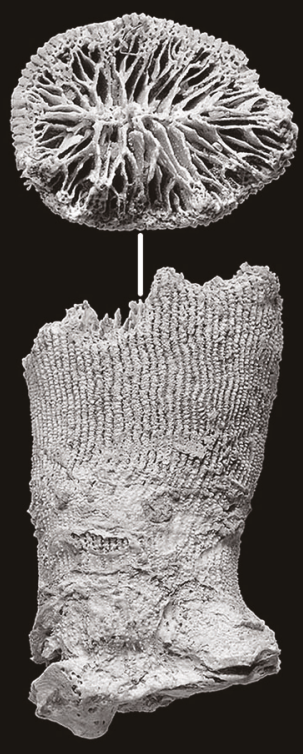

18

Figures 14-15. Undetermined Caryophyllidae. Zanclean of Monte Calcinaio. Figure 16. Flabellum cf. alabastrum Moseley, 1873. Zanclean of Pian delle Cortine. Figure 17. Dendrophyllia cf. ramea Linnaeus, 1758. Zanclean of Monte Calcinaio. Figure 18. Balanophyllia italica Michelin, 1841. Zanclean of Quercecchio. Scale bar $=10 \mathrm{~mm}$. 


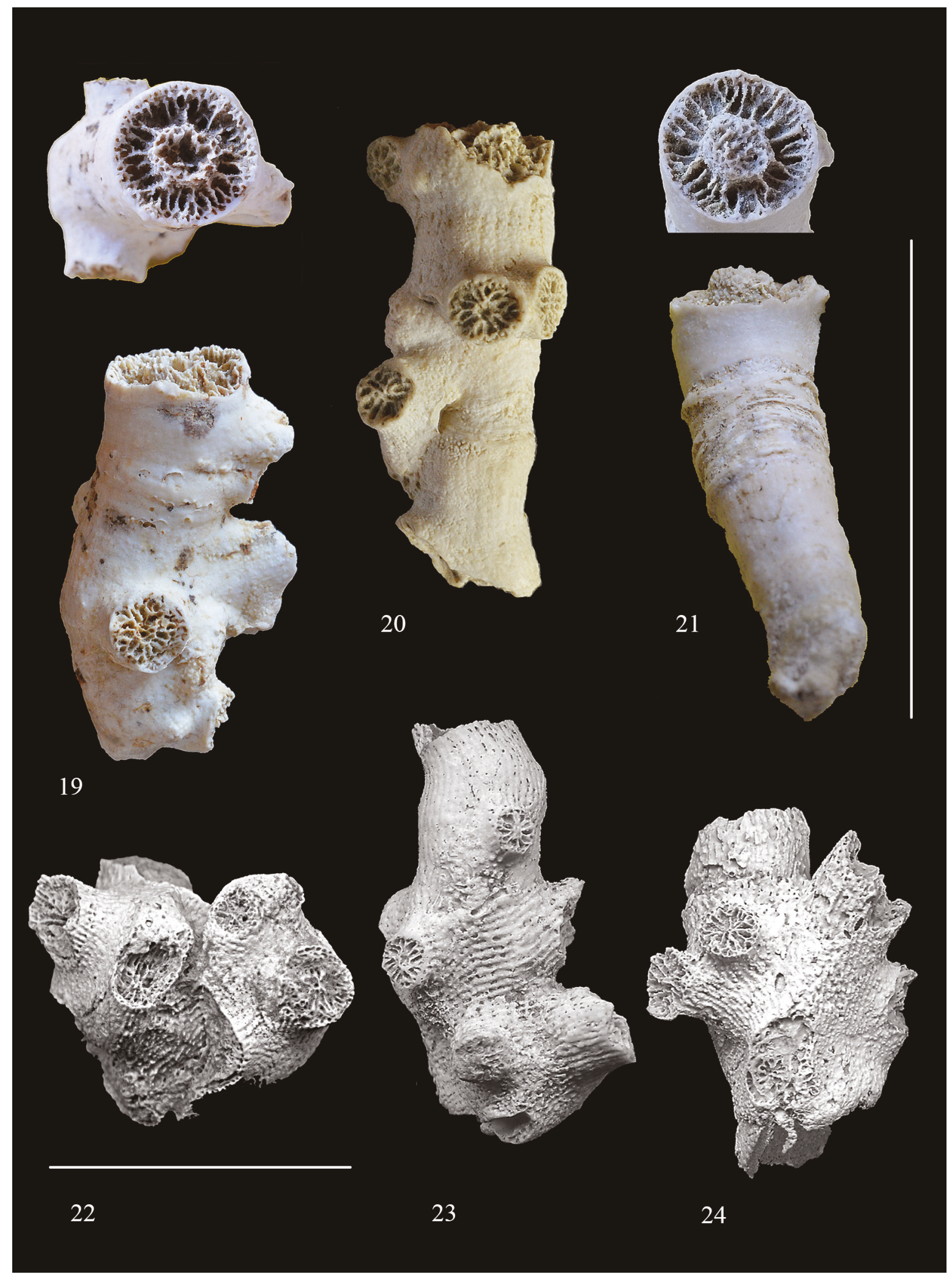

Figures 19-21. Cladopsammia sp. 1. Zanclean of Monte Calcinaio. (Scale bar $=10 \mathrm{~mm})$. Figures 22-24. Cladopsammia sp. 2. Zanclean of Monte Calcinaio. (Scale bar $=10 \mathrm{~mm}$ ). 
vermiculate with evident granulation, more evident and regular in lateral calices.

The septa are arranged in five incomplete cycles and number 60-70, but calices are never completely preserved. The characters of the columella could not be determined.

REMARKS. The colony is very incomplete and not all its characters can be fully determined. However, the two series of corallites appear to be compatible with $D$. ramea.

Stratigraphic OCCURREnCe. Dendrophyllia ramea has been reported from the Chattian and the Miocene of Aquitaine (Cahuzac \& Chaix). Michelin (1841) and Osasco (1895) report D. ramea from the Pliocene of Torrita di Siena and from the Piacentian of Zinola, respectively.

\section{CONCLUSIONS}

Sixty-six species of fossil scleractinians, belonging to 10 families and 30 genera, have so far been reported from the Pliocene of Siena (Siena, Radicofani and Valdichiana basins)(Spadini, 2015, 2016, 2018, 2020 and this paper). The best represented family is the Caryophylliidae with 15 genera and 32 species, one not assigned to any genus, followed by the Dendrophylliidae with five genera and 14 species and the Flabellidae with two genera and 11 species. The families Micrabaciidae, Faviidae and Rhizangiidae are represented by two species, and the Pocilloporidae, Siderastraeidae, Oculinidae and Stenocyathidae by only one species.

The present study reports five species new for this area (Caryophyllia cf. smithii, Anomocora sp., Flabellum cf. alabastrum, Balanophyllia italica, Dendrophyllia cf. ramea), other specimens not determined at species level (Trochocyathus sp., Cladopsammia sp.2), which will have to be confirmed by further research, and one species assigned to an undetermined genus of the Caryophylliidae.

This study also specifies some aspects of the morphology of Madracis almerai, Desmophyllum dianthus and Cladopsammia sp.1, common from the Pliocene of Monte Calcinaio. In addition, some aspects regarding the affinity of species first classified as Bathelia, now considered more similar to Sclerhelia, are specified.

The genus Anomocora is a new report from the
Pliocene of the Mediterranean. It is added to the list of various genera reported only from the Pliocene of Siena, in particular the Monte Calcinaio (Spadini, 2015, 2016, 2018, 2020). However, careful research has documented the presence of some of these genera in other sites, for example Bathelia and Pourtalosmilia have also been recovered from the Pliocene of Spain (Spadini, 2019) and Dasmosmilia from the Pliocene of Romagna (Spadini et al., 2020)

Further research will make it possible to widen the range of distribution of these genera and also to document their presence in other Mediterranean deposits.

\section{ACKNOWLEDGEMENTS}

I thank Francesco Pizzolato (Arezzo, Italy) for the help in the search for material and Helen Ampt (Siena, Italy) for revising the English.

\section{REFERENCES}

Cauhzac B. \& Chaix C., 1996. Structural and faunal evolution of Chattian-Miocene reefs and corals in Western France and Northeastern Atlantic Ocean. In: Franseen E., Esteban M., Ward W. \& Rouchy J.M. (Eds.), Models for Carbonate Stratigraphy from Miocene Reef Complexes of the Mediterranean Regions, Society of Economic Paleontologists and Mineralogists, Tulsa, Concepts in Sedimentology and Paleontology, 5: 105-127.

Cairns S.D. \& Kitahara M.V., 2012. An illustrated key to the genera and subgenera of the Recent azooxanthellate Scleractinia (Cnidaria, Anthozoa), with an attached glossary. ZooKeys, 227: 1-47.

Corselli B., 2010. Introduction: Cold-Water communities in the Mediterranean Sea. Deep-Sea Research II (2010): 323-325.

De Angelis G., 1894. I corallari dei terreni terziari dell'Italia settentrionale. Collezione Michelotti, Museo geologico della R. Universita di Roma. Atti della R. Accademia dei Lincei, Memorie della Classe di Scienze Fisiche, Matematiche e Naturali 5: 164-280.

De Stefani T., 1955. Considerazioni geologiche sulla frana di Naso. Rivista Mineraria Siciliana, 31: 1419.

Jüssen E., 1890. Über Pliocäne Korallen von der Insel Rhodus. Sitzungsberichte der Kaiserlichen Akademie der Wissenschaften, Wien, mathematisch-naturwissenschaftliche, 99: 13-23. 
Kühn O., 1965. Korallen und Bryozoen aus der bayerischen Molasse. Mitteilungen der Bayerischen Staatssammlung für Paläontologie und historische Geologie, 5: 29-68.

Michelin J.H.L., 1840-1847. Iconographie zoophytologique. Description par localitès et terrain des Polypiers fossiles de France et des pays envirronnants. 348, pages, 79 tavv. Paris: P. Bertrand Editeur.

Montanaro E., 1929. Coralli tortoniani di Montegibbio (Modena). Bollettino della Società Geologica Italiana, 48: 107-127.

Montanaro E., 1931. Coralli pliocenici dell'Emilia. Palaeontographia Italica, 31:63-91.

Namias I., 1891. Coralli fossili del Museo geologico della R. Università di Modena. Atti della Società dei naturalisti di Modena, Serie III, 8: 93-108.

Osasco E., 1895. Di alcuni corallari pliocenici del Piemonte e della Liguria. Atti della Regia Accademia delle Scienze Torino 31: 225-238.

Placella B., 1978. Nuove osservazioni sulla corallofauna delle argille pleistoceniche di Archi (Reggio Calabria). Bollettino della Società Naturalistica di Napoli, 87: 1-23.

Reuss A.E. von, 1871. Die fossilen korallen des Östrerreichisch-Ungarischen Miocäns. Denkschriften der kaiserlichen Akademie der Wissenschaften, 31: 197_ 270

Russo A., 1980. The psychrospheric coral fauna from the Lower Pliocene of Northern Italy. Acta Paleontologica polonica, 25: 613-617.

Scacchi A. 1835. Notizie intorno alle conchiglie ed a' zoofiti fossili che si trovano nelle vicinanze di Gravina in Puglia. Annali Civili del Regno delle Due Sicilie 6 : 75-84; 7: 5-18, $2 \mathrm{pl}$.

Seguenza G., 1864. Disquisizioni paleontologiche intorno ai Corallarii fossili delle rocce terziarie del distretto di Messina. Memorie della reale Accademia delle Scienze di Torino, Classe di scienze fisiche matematiche e naturali, (2) 21:399-560, 15 tav.

Seguenza G., 1880. Le formazioni terziarie della provincia di Reggio (Calabria). Atti della regia Accademia dei Lincei, memorie della Classe di scienze Fisiche, Chimiche e Naturali, (3)12: 65-217.

Sganga P., 1978. La sezione stratigrafica calabriana di Naso (Messina). Rivista Mineraria Siciliana, 14: 82 84: 3-23, 11 tavv.

Simonelli V., 1895. Gli Antozoi pliocenici del Ponticello di Savena presso Bologna. Paleontographia Italica, 1: $149-168$

Simonelli V., 1896. Antozoi neogenici del Museo Parmense. Paleontographia Italica, 2: 185-201.

Sismonda E., 1871. Matériaux pour servir à la paléon- tologie du terrain tertiaire du Piémont. Memorie della Reale Accademia delle scienze di Torino, 2: 257-361. Spadini V., 2015. Sclerattiniari del Pliocene senese (Cnidaria, Anthozoa). Accademia delle Scienze di Siena detta dei Fisiocritici, p. 159.

Spadini V., 2016. First occurrence of the genus Bathelia (Anthozoa, Scleractinia) from the Mediterranean Pliocene. Bollettino della Società Paleontologica Italiana, 55: 219-222.

Spadini V., 2018. The genus Crispatotrochus TenisonWoods, 1878 (Anthozoa, Scleractinia) from the Mediterranean Pliocene Biodiversity Journal, 9: 345350.

https://doi.org/10.31396/Biodiv.Jour.2018.9.4.345.350

Spadini V., 2019. Pliocene Scleractinians From Estepona (Malaga, Spain) Atti della Società Toscana di Scienze Naturali, Memorie, Serie A, 126: 75-94. https://doi.org/10.2424/ASTSN.M.2019.14

Spadini V., 2020. New report of shallow water scleractinians from the Pliocene of Siena. Biodiversity Journal, 11: 815-819.

https://doi.org/10.31396/Biodiv.Jour.2020.11.4.815.819

Taviani M., Freiwald A. \& Zibrowius H., 2005. Deep coral growth in the Mediterranean Sea: an overview. In: Freiwald A., Roberts J.M. (Eds.), Cold-water Corals and Ecosystems. Springer-Verlag Berlin Heidelberg, pp 137-156.

Taviani M, Freiwald A. \& Zibrowius H., 2005. Deepcoral growth in the Mediterranean Sea: an overview. In: Freiwald A. \& Roberts J.M. (Eds.), Cold-water corals and ecosystems. Springer, Heidelberg, Berlin, pp 137-156.

Taviani M., Vertino A., Angeletti L., Montagna P. \& Remia A., 2019. Paleoecology of Mediterranean Cold-Water Corals. In: Covadonga O. \& Jiménez C. (Ed.), Mediterranean Cold-Water Corals: Past, present and Future, Springer, pag. 15-30. https://doi.org/10.1007/978-3-319-91608-8_2

Vertino A., 2003. Sclerattiniari plio-pleistocenici ed attuali del Mediterraneo. PhD dissertation, University of Messina.

Vertino A., Stolarski J. \& Bosellini F.R., 2014. Mediterranean corals through time: from Miocene to present. In: Goffredo S. \& Dubinsky Z. (Eds.), The Mediterranean Sea: its history and present challenges. Springer, Dordrecht, pp. 257-274.

Vertino A., Taviani M. \& Corselli C., 2019. Spatio-Temporal Distribution of Mediterranean Cold-Water Corals. In: Covadonga O. \& Jiménez C. (Ed.), Past, present and Future, Springer, pag. 67-84. https://doi.org/10.1007/978-3-319-91608-8 9

Zibrowius H., 1980. Les Scléractiniaires de la Méditeranée et de l'Atlantique nord-oriental. Memoires de l'Institut Océanographique, Monaco, 11: 284 pp. 